\title{
PRODUK PERUSAHAAN PEMBIAYAAN DAN TEKNIK PENCATATAN SECARA AKUNTANSI SEBAGAI PENDUKUNG AKTIVITAS USAHA
}

\author{
${ }^{1}$ Jurusan Manajemen, Universitas Tarumanagara Jakarta \\ E-mail : halimputera@yahoo.com \\ E-mail : margaritae@fe.untar.ac.id \\ ${ }^{2}$ Jurusan Akuntansi, Universitas Tarumanagara Jakarta \\ E-mail : henny@fe.untar.ac.id \\ E-mail : agustine@ fe.untar.ac.id
}

Halim Putera Siswanto1, Margarita Ekadjaja ${ }^{1}$, Henny $^{2}$, Agustin Ekadjaja ${ }^{2}$.

\begin{abstract}
ABSTRAK
Menjadi wirausahawan (entrepreneur) adalah pilihan yang menantang, karena selain dibutuhkan soft skill untuk melaksanakan kegiatan usahaanya juga diperlukan dana yang cukup untuk membiayai kegiatan usahanya. Suatu kondisi keuangan yang sehat dapat dicapai jika seseorang sudah mengetahui dengan jelas tujuan yang akan dicapai dan mampu mengelola sumber daya keuangannya secara tepat guna mencapai tujuan dimaksud. Selama tujuan penggunaan dari barang atau jasa tersebut merupakan suatu kebutuhan untuk tujuan produktif, maka meminjam dari sumber dana lain seperti perusahaan pembiayaan adalah keputusan yang dapat dibenarkan. Masih terdapat banyak pengusaha Usaha Mikro Kecil Menengah (UMKM) di Indonesia yang memiliki ide-ide usaha kreatif namun belum mendapatkan akses layanan dari jasa pembiayaan yang ada. Hal ini disebabkan karena minimnya pengetahuan mereka tentang perusahaan pembiayaan, analisis kredit, dan teknik pencatatan secara akuntansi. Hal ini yang mendorong perlu dilakukannya program Pengabdian Kepada Masyarakat (PKM). Program PKM ini berupa pelatihan kepada perusahaan Multi Global Electrindo, dikarenakan perusahaan tersebut merupakan perusahaan perseorangan dengan jumlah karyawan yang masih relatif sedikit dan masih memerlukan dana besar. Program PKM ini didanai oleh Direktorat Penelitian Pengabdian Masyarakat Universitas Tarumanagara (DPPM UNTAR). Tujuan pelaksanaan kegiatan PKM ini adalah dapat menghasilkan kontribusi positif bagi entrepreneur dalam hal peningkatan pemahaman mengenai literasi keuangan dan juga sebagai pemicu kegiatan-kegiatan PKM lanjutan untuk membantu program pemerintah dalam hal pengenalan literasi keuangan melalui Universitas Tarumanagara yang mendanai kegiatan ini.
\end{abstract}

Kata kunci : UMKM, entrepreneur, perusahaan pembiayaan, kredit, akuntansi

\section{PENDAHULUAN}

Dalam upaya memenuhi kebutuhan hidupnya terutama dalam hal pengelolaan keuangan, wirausahawan dapat memilih produk dari industri jasa keuangan yang diatur dan diawasi oleh Otoritas Jasa Keuangan (OJK). Salah satu yang dapat dipilih adalah produk pembiayaan yang ditawarkan oleh perusahaan pembiayaan.

Pembiayaan menurut Siamat (2005) adalah penyediaan dana oleh perusahaan pembiayaan untuk membiayai kebutuhan debitur dalam memperoleh barang/jasa melalui pihak ketiga (dealer/toko/supplier) sebagai penyedia barang/jasa dengan cara mengangsur. Berdasarkan perjanjian pembiayaan dengan debitur, kreditu mewajibkan debitur untuk melunasi utangnya dalam jangka waktu tertentu berikut bunga dan biaya lainnya.

Jenis barang/jasa yang dapat dibiayai oleh perusahaan pembiayaan pada prinsipnya menjadi dua kategori (Kashmir, 2015), yaitu pembiayaan produktif dan pembiayaan konsumtif. Pembiayaan produktif adalah untuk memenuhi kebutuhan usaha produktif dalam arti luas, baik untuk keperluan pengembangan usaha (sebagai produsen atau pedagang) mapun untuk keperluan investasi (kebutuhan akan barang modal). Contoh pembiayaan produktif antara lain pembelian bahan baku, barang dagangan, atau pembelian/penambahan mesin-mesin produksi. Pembiayaan konsumtif 
adalah pembiayaan untuk memenuhi kebutuhan debitur terhadap barang/jasa habis pakai, contohnya rumah tinggal, kendaraan bermotor untuk transportasi, biaya kesehatan, biaya pendidikan, dan lain sebagainya.

Masih terdapat banyak pengusaha Usaha Mikro Kecil Menengah (UMKM) di Indonesia yang memiliki ide-ide usaha kreatif namun belum mendapatkan akses layanan dari jasa pembiayaan yang ada, karena minimnya pengetahuan mereka tentang perusahaan pembiayaan (Rivai, 2012). Sementara sumber pembiayaan pelaku UMKM pada saat ini semakin terbuka lebar setelah masuknya sejumlah perusahaan financial technology (fintech) yang bergerak dibidang pinjam meminjam langsung atau Peer-to-Peer Lending (P2P Lending). Namun beberapa UKM yang dinilai kurang bankable masih mengalami kesulitan dalam mengakses pembiayaan. Dengan demikian edukasi tentang perusahaan pembiayaan menjadi semakin penting agar pemberdayaan UMKM nasional dapat semakin ditingkatkan.

Menurut Noel (2012) dalam mengelola keuangan, ada kalanya sesorang perlu berhutang atau meminjam dana untuk mewujudkan keinginannya dalam membeli suatu produk barang atau jasa. Mendapatkan pinjaman atau pembiayaan dari perusahaan pembiayaan dengan disertai suatu perhitungan pengelolaan keuangan yang tepat akan membantu mempercepat perolehan dana dalam meningkatkan kemampuan keuangan terutama dalam meningkatkan kinerja usaha yang sedang dilakukan (Miskhin, 2009).

Kebutuhan tersebut direspon oleh beberapa dosen tetap FE-UNTAR yang sudah mendapatkan sertifikasi dosen untuk melakukan Pengabdian Kepada Masyarakat (PKM). Kami selaku dosen tetap FE-UNTAR yang telah memiliki bekal pengetahuan tersebut merasa terpanggil untuk menjadi saluran berkat dengan cara membagikan pengetahuan kepada mereka yang membutuhkannya.

Dalam upaya mendukung kegiatan usaha perusahaan Multi Global Electrindo dalam hal pembiayaan, maka diperlukan edukasi mengenai produk-produk pembiayaan yang ada, memilih skema pembiayaan sesuai kebutuhan, dan berikut pencatatannya secara akuntansi.

Edukasi yang diberikan sehubungan dengan program pengabdian kepada masyarakat ini diberikan dalam bentuk pelatihan, dengan pembatasan permasalahan sebagai berikut:

a. Bagaimanakah cara memahami kebutuhan dan memilih alternatif pembiayaan yang tepat?

b. Apa sajakah kewajiban dan risiko dari alternatif pembiayaan yang dipilih?

c. Bagaimanakah mekanisme pengajuan kredit dan penyelesaian perselisihan apabila terdapat perbedaan?

d. Berapakah besarnya biaya kredit dan jumlah kredit yang dapat diberikan sesuai kemampuan?

e. Bagaimanakah pecatatan dan perhitungannya secara akuntansi?

\section{METODE PELAKSANAAN PKM}

a. Ruang Lingkup

Pembicara dalam pelatihan ini terdiri atas empat orang, yang mana setiap pembicara membawakan tiga topik materi pelatihan selama kurang lebih satu jam, dan pada akhir pelatihan diberikan angket dan tes sebagai dasar pengukuran atas keberhasilan kegiatan pelatihan ini.

Adapun materi pelatihan ini meliputi: (1) Memahami pengelolaan keuangan secara efektif (2) Pengenalan produk perusahaan pembiayaan (3) Manfaat produk pembiayaan (4) Kewajiban dan risiko (5) Kerahasiaan data dan dokumen perjanjian pembiayaan (6) Mekanisme penyelesaian 
perselisihan (7) Memilih skema pembiayaan sesuai kebutuhan (8) Memilih jangka waktu pembiayaan sesuai kemampuan (9) Faktor-faktor yang mempengaruhi pemberian kredit (10) Pengenalan kredit yang berbasis teknologi (Peer-to-Peer Lending) (11) Pencatatan kredit secara akuntansi (12) Simulasi perhitungan biaya kredit.

b. Waktu dan Lokasi Kegiatan

Terdapat dua kegiatan yang telah dilakukan yaitu:

(1) Pembuatan Modul Produk Pembiayaan dan Pencatatannya Secara Akuntansi $\rightarrow$ disusun dari bulan Februari s/d Maret 2018.

(2) Pelatihan \& Diskusi telah dilaksanakan pada:

Hari/Tgl. : 9 April 2018

Waktu : Pk. 09.00 WIB s/d selesai

Tempat : $\quad$ Perusahaan Multi Global Electrindo

Acara : - $\quad$ Pelatihan

- $\quad$ Makan siang bersama

- $\quad$ Diskusi

- $\quad$ Simulasi kredit

Kegiatan pelatihan ini dikemas dalam bentuk ceramah, tanya jawab, dan latihan soal. Evaluasi dilakukan pada akhir kegiatan pelatihan ini dengan menyebarkan angket mengenai minat peserta atas topik bahasan dan keberlanjutan kegiatan ini.

\section{Tahapan Kegiatan PKM}

Dalam pelaksanaan kegiatan PKM dibagi menjadi beberapa tahapan, meliputi :

Tahap 1 : Menganalisis kebutuhan pelatihan

Pada tahap ini, tim PKM mengadakan rapat pendahuluan untuk membahas tema kegiatan PKM yang akan dilakukan pada semester genap 2017/2018. Dalam rapat tersebut, kami mendapatkan gagasan untuk memberikan pelatihan mengenai kegiatan perusahaan pembiayaan dan analisis kredit pada perusahaan Multi Global Electrindo. Hasil rapat tersebut langsung kami koordinasikan dengan pihak perusahaan, dan gagasan tersebut dapat diterima dengan baik.

Tahap 2 : Membuat proposal

Pada tahap selanjutnya, tim segera membuat proposal dan mengajukan dana untuk pelaksanaan kegiatan PKM ke Direktorat Penelitian Pengabdian Masyarakat Universitas Tarumanagara (DPPM UNTAR) sesuai dengan format dan batas waktu yang ditentukan.

Tahap 3 : Menyusun materi pelatihan

Setelah proposal disetujui, tim segera melakukan rapat kembali untuk menyusun materi pelatihan, jadwal acara, dan pembagian tugas.

Tahap 4 : Membuat modul pelatihan

Tahap selanjutnya tim membuat modul pelatihan sesuai dengan materi yang akan disampaikan dalam pelatihan tersebut.

Tahap 5 : Mempersiapkan pelatihan

Setelah dana yang disetujui DPPM UNTAR dapat diambil, maka kami mengadakan rapat kembali bersama tim guna mempersiapkan kegiatan pelatihan.

Tahap 6 : Pelaksanaan pelatihan

Pelaksanaan pelatihan dilakukan tepat waktu sesuai dengan jadwal acara yang ditentukan dan berjalan dengan baik.

Tahap 7 : Evaluasi dan penyusunan laporan akhir

Setelah pelaksanaan pelatihan selesai, tim melakukan evaluasi singkat dan segera menyusun laporan akhir kegiatan. 
Tahap 8 : Monev dan penyerahan laporan akhir

Tahap terakhir dalam kegiatan PKM ini adalah ketua tim mengikuti kegiatan monev guna mempertanggungjawabkan kegiatan PKM serta menyerahkan laporan akhir.

\section{HASIL DAN PEMBAHASAN}

a. Hasil Kegiatan PKM

Kegiatan dimulai pada Pk. 09.00 WIB dengan agenda acara seperti yang dapat dilihat pada Tabel 1 sebagai berikut:

Tabel 1. Pelaksanaan Kegiatan PKM

\begin{tabular}{cl}
\hline Waktu & \multicolumn{1}{c}{ Acara Kegiatan } \\
\hline $09.00-09.30$ & Pembukaan dan sambutan \\
\hline $09.30-13.00$ & $\begin{array}{l}\text { Pengenalan produk-produk pembiayaan (Sesi 1,2,3,4) } \\
\text { disertai sesi tanya-jawab dan simulasi perhitungan kredit }\end{array}$ \\
\hline $13.00-14.00$ & Makan siang \\
\hline $14.00-15.00$ & Penutupan dan pemberian cindera mata dan foto bersama \\
\hline
\end{tabular}

Para karyawan yang ikut serta dalam kegiatan pelatihan secara keseluruhan terdiri dari delapan orang, dengan tingkat pendidikan yang bervariasi, yakni lulusan dari Sekolah Menengah Kejuruan (SMK), Akademi, dan Universitas (S-1). Materi pelatihan dibagi ke dalam empat sesi, yang meliputi :

Sesi 1: Pengenalan mengenai perusahaan pembiayaan

Dalam sesi ini dibahas mengenai pengelolaan keuangan secara efektif, pengenalan produk perusahaan pembiayaan, dan manfaat produk pembiayaan.

Sesi 2: Hal-hal yang harus diperhatikan dalam perusahaan pembiayaan

Dalam sesi ini dibahas mengenai kewajiban dan risiko, kerahasiaan data dan dokumen perjanjian pembiayaan, serta mekanisme penyelesaian perselisihan.

\section{Sesi 3: Analisis kredit}

Dalam sesi ini dibahas mengenai memilih skema pembiayaan sesuai kebutuhan, memilih jangka waktu pembiayaan sesuai kemampuan, faktor-faktor yang mempengaruhi pemberian kredit, serta pengenalan kredit yang berbasis teknologi (Peer-to-Peer Lending).

Sesi 4: Pencatatan kredit secara Akuntansi

Dalam sesi ini dibahas mengenai pencatatan kredit secara akuntansi dan simulasi perhitungan biaya kredit.

Sebagai kontribusi, panitia juga memberikan beberapa keperluan pelatihan untuk disumbangkan kepada perusahaan seperti: souvenir dari FE UNTAR (map, notebook, pen @ 8 buah) yang dibagikan kepada seluruh peserta pelatihan dan beberapa souvernir lainnya (tanda terima panitia dapat dilihat pada bagian lampiran) guna menunjang pelaksanaan kegiatan pelatihan ini.

\section{Target Pelaksanaan Kegiatan PKM}

Target pelatihan ini adalah karyawan di semua bidang pekerjaan, dikarenakan pelatihan ini bersifat umum yang membantu dalam hal penyediaan dana bagi perseorangan maupun perusahaan dalam membiayai kebutuhan/kelangsungan hidup. Jika mereka berminat untuk melakukan wirausaha maka pengetahuan/ketrampilan yang diperoleh dari kegiatan pelatihan ini dapat mereka terapkan. Untuk itu, di dalam pelatihan ini juga disisipkan motivasi untuk pembentukan mental yang mandiri serta tantangan untuk menjadi wirausaha yang tangguh. 


\section{Luaran yang dicapai}

Luaran dari kegiatan PKM ini adalah berupa modul Workshop mengenai Perusahaan Pembiayaan dan Teknik Pencatatan secara Akuntansi, yang berisi tentang perusahaan pembiayaan dan produkproduknya, teknik pencatatan secara akuntansi, dan simulasi perhitungan kredit, dan disertai dengan contoh soal dan beberapa latihan soal. Modul ini akan dipakai sebagai kontribusi bahan ajar untuk mahasiswa FE-UNTAR, terutama di dalam mata kuliah Bank dan Lembaga Keuangan (BLK), Manajemen Keuangan, dan Manajemen Kredit. Modul ini dapat memberikan manfaat dalam hal pemberian informasi sehubungan dengan perolehan pembiayaan untuk suatu kegiatan usaha.

Luaran lainnya adalah berupa artikel yang dipublikasikan di dalam kegiatan Senapenmas yang diselenggarakan oleh Universitas Tarumanagara, sehingga dapat diperoleh beberapa saran yang bermanfaat demi perbaikan untuk kegiatan PKM selanjutnya.

Luaran yang diperoleh dari hasil kegiatan PKM yang sangat berguna bagi perusahaan adalah para personil mereka dapat mengetahui secara lebih mendalam mengenai produk pembiayaan dan mereka pada akhirnya dapat memahami teknik analisis kredit dan pencatatannya secara akuntansi.

Luaran selanjutnya yang diperoleh dari hasil kegiatan PKM ini adalah menyertakan mahasiswa FE-UNTAR untuk ikut berperan serta di dalam kegiatan PKM sehingga dapat memberikan pengalaman dan ketrampilan kepada mahasiwa tersebut agar dapat siap bekerja setelah menyelesaikan pendidikannya di FE-UNTAR.

Berikut ini adalah tampilan secara visual dari kegiatan PKM yang telah dilakukan.

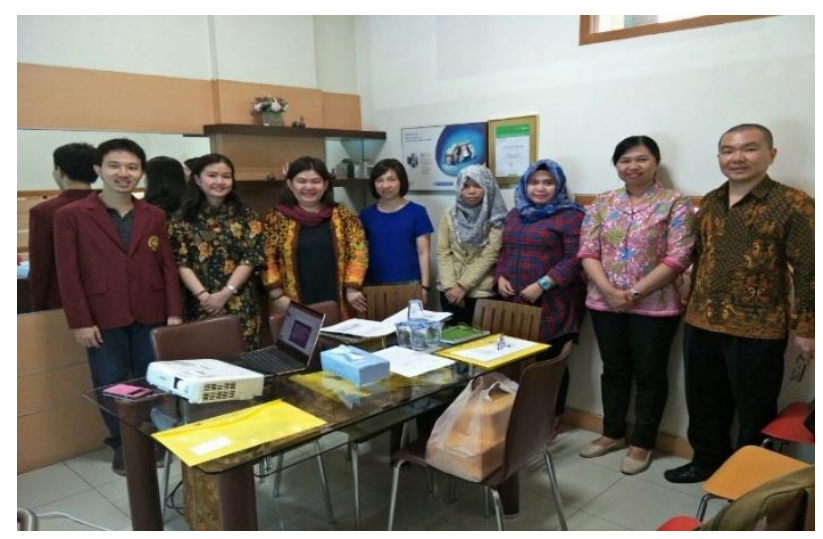

Gambar 1. Tim PKM FE UNTAR bersama peserta pelatihan di MGE

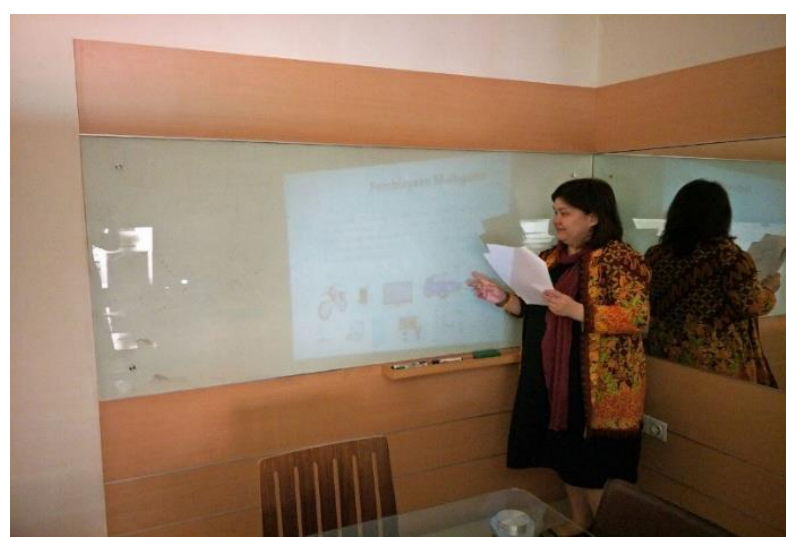

Gambar 2. Pembicara Sesi 1 : Margarita Ekadjaja, S.E., M.M 


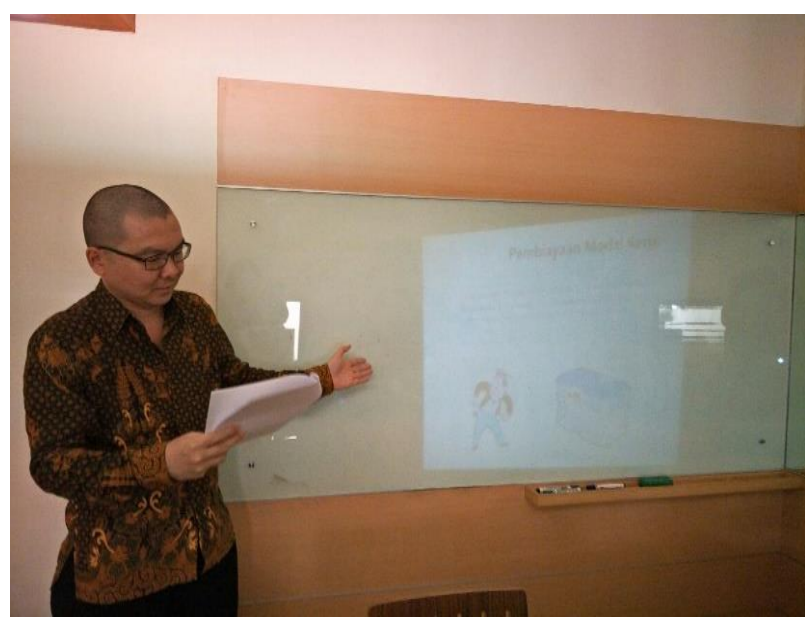

Gambar 3. Pembicara Sesi 2 : Halim Putera Siswanto, S.E., M.M.

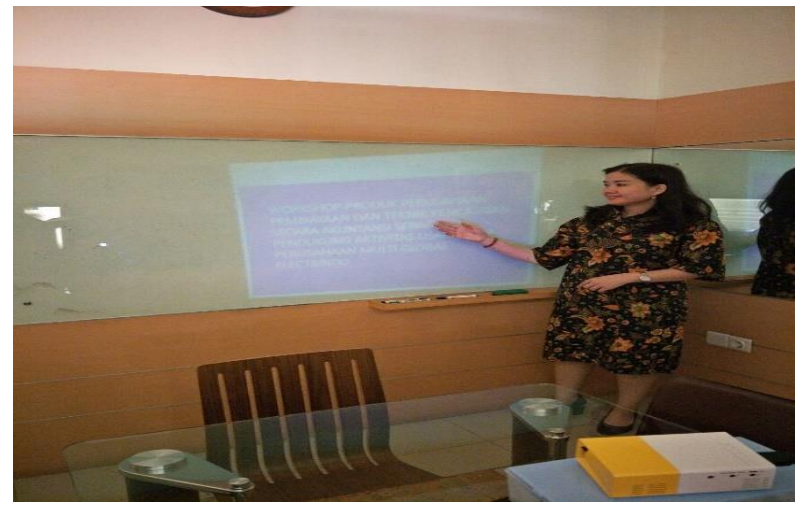

Gambar 5. Pembicara Sesi Akhir : Agustin Ekadjaja, S.E., M.Si., Ak.,C.A.

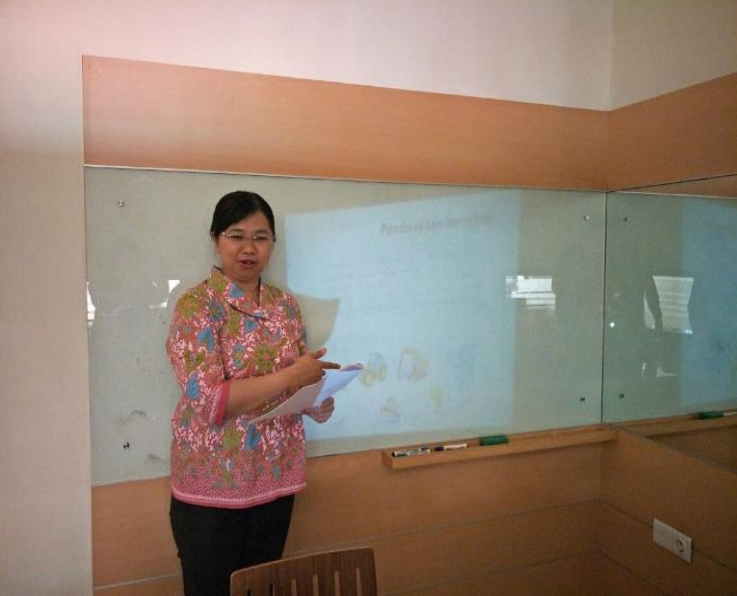

Gambar 4. Pembicara Sesi 3 : Henny, S.E., M.Si., Ak., B.K.P., C.A.

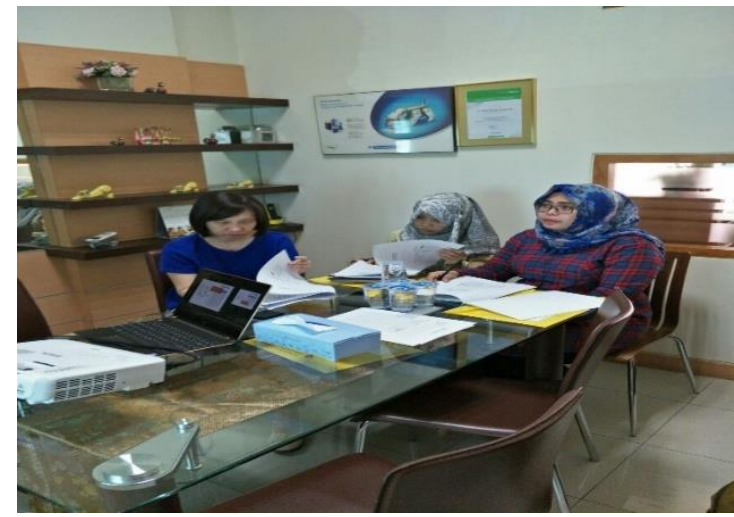

Gambar 6. Sesi Simulasi Kredit dan Tanya-Jawab

\section{KESIMPULAN}

\section{a. Kesimpulan}

Kegiatan pelatihan ini dapat disimpulkan telah berjalan dengan baik. Para peserta sangat antusias dengan pelaksanaan kegiatan ini. Para peserta dapat memahami materi pelatihan dengan baik karena selain diberikan materi bersifat teoritis, para peserta juga diberikan simulasi perhitungan kredit berikut contoh soal yang up-to-date. Kesimpulan ini didasarkan pada adanya permintaan dari pimpinan perusahaan agar kegiatan ini dapat berlanjut karena berguna untuk menunjang kelangsungan kegiatan usaha mereka.

\section{b. Implikasi}

Implikasi dari kegiatan PKM ini adalah meningkatnya kemampuan peserta pelatihan di dalam melakukan analisis perhitungan kredit dan teknik pencatatannya secara akuntansi, serta adanya keterlibatan mahasiswa untuk ikut berperan aktif di dalam kegiatan PKM dan pembelajaran bagi mahasiswa agar siap bekerja setelah lulus kuliah. Namun keterbatasan fasilitas seperti komputer dan suasana ruangan membuat para peserta kurang maksimal di dalam mempelajari perhitungan nilai pinjaman dengan menggunakan software aplikasi yang ada. 
Selain itu, juga terdapat keterbatasan waktu di kalangan para peserta pelatihan dikarenakan jadwal kegiatan mereka yang cukup padat saat bekerja di kantor.

Oleh karena itu, tim PKM mendapatkan saran agar kegiatan pelatihan ini dapat dilanjutkan pada kunjungan berikutnya dengan membawakan materi pelatihan lanjutan.

\section{REFERENSI}

Kashmir. (2015). Bank dan Lembaga Keuangan Lainnya. Edisi Revisi. PT. Raja Grafindo Persada, Jakarta.

Mishkin, FS. (2009). Money and Banking. McGraw-Hill, New Jersey.

Rivai, V. (2012). Commercial Bank Management: Manajemen Perbankan dari Teori ke Praktik, Cetakan Pertama. PT. Raja Grafindo Persada, Jakarta.

Siamat, D. (2005). Manajemen Lembaga Keuangan. Edisi Kelima. Fakultas Ekonomi Universitas Indonesia, Jakarta.

Tohir, NC. (2012). Panduan Lengkap Menjadi Account Officer. PT. Elex Media Komputindo, Jakarta. 